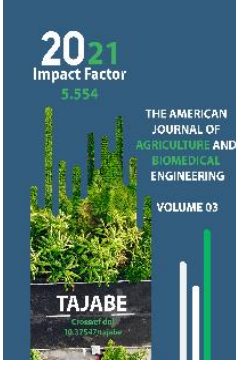

\title{
Prospects For Technical Modernization Of Agriculture
}

\section{Yusupov Z.Z.}

Independent Researcher, Tashkent State Agrarian University, Uzbekistan

Copyright: Original

content from this work may be used under the terms of the creative commons attributes 4.0 licence.

\section{ABSTRACT}

The article presents the results of the ongoing reforms to improve the technical potential in agriculture and the conclusions arising from this, as well as recommendations for a further qualitative and quantitative increase in the technical potential of the agricultural sector.

\section{KEYWORDS}

Agricultural Machinery, Holding, Joint-Stock Company, “UzKeysmash”, “UzKeystraktor”, “UzKlaasagro”, “Lemken- Chirchik”, Leasing.

\section{INTRODUCTION}

In Uzbekistan, the agricultural sector plays a special role in the development of our economy. Therefore, the economic reforms carried out since independence has focused on increasing its efficiency and sustainable development of the industry. Along with the 
development of various forms of ownership and the rapid development of farms as a promising form of management, special attention has been paid to the modernization of them and agricultural production in general, increasing its technical and technological potential. During the years of independence, the Government of the Republic has adopted a number of regulations to increase the technical capacity of the agricultural sector.

In particular, in order to maintain and further strengthen the existing technical potential of crop production in agriculture after independence and to consolidate highperformance equipment, the Cabinet of Ministers of the Republic of Uzbekistan dated March 24, 1995 No. 95 "On measures to develop contractual relations in agricultural production and maintenance". According to it, on the basis of the old "Selkhoztekhnika Agricultural machinery" departments in the districts, the State Joint-Stock Company Machine-Tractor Parks (JSC MTP) was established and their number was increased to 185. After that, under the state guarantee began to import high-performance equipment from the "Keys" Corporation, a leading US agricultural machinery plant on a lease basis. Subsequently, in order to maintain the existing technical capacity of the farms of the former company, the Decree No. 106 of March 10, 1998 "On measures to further strengthen the material and technical base of machine and tractor fleets and expand their services" began to establish alternative tractor fleets, at that time and their number reached 1641, and now they have at their disposal more than 16,124 tractors of various models.

\section{THE MAIN FINDINGS AND RESULTS}

Recognizing that the agricultural sector of Uzbekistan cannot be developed sustainably without agricultural machinery, and to provide the republic's agriculture with modern equipment and mechanization; formation of a management structure of agricultural machinery that meets market conditions, as well as achieving stable and efficient operation of enterprises in the sector; In order to increase the competitiveness of their products, on January 31, 1996, the Cabinet of Ministers of the Republic of Uzbekistan adopted Resolution No. 45 "On the establishment of a holding company" "Agricultural Machinery - Holding Uzbekistan", after that the holding company "Agricultural Machinery - Holding of Uzbekistan" was established.

During the years of independence, as a result of the creation of a solid legal and regulatory framework for the broad development of leasing relations in the country, the increase in the number of different leasing companies has led to increased competition between them. Most commercial banks and credit institutions have also begun to implement their own leasing programs. Purchase of agricultural machinery under leasing has become one of the main requirements of the agricultural sector and serves as an important tool for improving the technical and technological capacity of the industry.

Radical increase in the level of equipping agriculture and processing industries with modern high-efficiency agricultural machinery and technological equipment produced in our country, meeting world requirements and standards; foreign investment for modernization, technical and technological renewal of agricultural machinery enterprises; first of all, in order to attract more foreign direct investment of leading foreign companies, the President of the Republic of Uzbekistan dated May 21, 2012 No. PD-1758 "Further modernization of agricultural production in 2012-2016"; the adoption of the 
resolution "On the program of technical and technological re-equipment" has eliminated these negative trends and made a radical turn in this direction in the history of our country.

It is no exaggeration to say that the adoption of this decision marked a new stage in the development of agricultural machinery in our country. Among the innovations should be noted the establishment of a specialized design bureau for the creation of modern agricultural machinery. This structure specializes in the design of machinery and equipment, taking into accounts the specifics of agricultural production of the country and the requirements for tillage, planting, harvesting techniques used in the production of cotton, vegetables, horticulture, viticulture and feed.

In addition, due to the creation of favorable organizational, economic and legal conditions for foreign investors, the number of joint ventures producing modern agricultural machinery with the participation of developed countries is growing, including: "UzKeysmash", “UzKeystraktor", "UzKlaasagro", "Lemken- Chirchik" and other joint ventures.
In short, during the years of independence, the basis of modernization, technical and technological capacity building of agriculture in the country consisted of three stages, the first stage covering 1995-1998; efforts were made to maintain the existing technical and technological potential and the introduction of modern equipment and technologies. The second stage covers the years 1999-2011, during which the joint ventures produced modern agricultural machinery and provided them with the agricultural sector, and as a result increased the technical and technological potential of agriculture.

And finally the third phase started in 2012 and continues to this day. During this period, the management system of the agricultural machinery system was improved. On the basis of the adopted complex programs, the technical and technological potential of agriculture has been raised to a new level. (Table 1)

The results of the analysis of reforms carried out during the years of independence in the field of modernization, technical and technological renewal of agriculture in the country are the basis for the following conclusions:

Table 1

The main stages of increasing the technical potential of agriculture in the country during the years of independence

(Source: Based on the authors' research)

\begin{tabular}{|c|c|c|}
\hline Stages & The main activities carried out & Achieved results \\
\hline $\begin{array}{c}\text { Stage I 1995- } \\
1998\end{array}$ & $\begin{array}{l}\text { Resolution of the Cabinet of Ministers of the Republic of } \\
\text { Uzbekistan } 1995 \text { By Resolution No. } 95 \text { of } 24 \text { March, JSC } \\
\text { MTPs were established, bringing their number to } 185 \text {. By } \\
\text { Resolution No. } 106 \text { of March 10, 1998, alternative MTPs } \\
\text { were established and their number increased to 196. On } \\
\text { January } 31,1996 \text {, the Resolution of the Cabinet of Ministers } \\
\text { of the Republic of Uzbekistan No. } 45 \text { "On Establishment of }\end{array}$ & $\begin{array}{l}\text { Efforts were made to } \\
\text { maintain the existing } \\
\text { technical and technological } \\
\text { potential, and the } \\
\text { introduction of modern }\end{array}$ \\
\hline
\end{tabular}


The American Journal of Agriculture and Boimedical Engineering

(ISSN - 2689-1018)

IMPACT FACTOR

Published: April 21, 2021| Pages: 6-11

Doi: https://doi.org/10.37547/tajabe/Volume03Issue04-02

2021: $5 \cdot 554$

OCLC - 1121105746

\begin{tabular}{|c|c|c|}
\hline & $\begin{array}{l}\text { Agricultural Machinery - Holding of Uzbekistan" Holding } \\
\text { Company was adopted. }\end{array}$ & $\begin{array}{l}\text { equipment and technologies } \\
\text { was initiated }\end{array}$ \\
\hline Stage II & $\begin{array}{l}\text { In 1999, the Oliy Majlis of the Republic of Uzbekistan } \\
\text { adopted the Law "On Leasing". } 2000 \text { of the Cabinet of } \\
\text { Ministers of the Republic of Uzbekistan In accordance with } \\
\text { the resolution of November } 20 \text { "On measures to provide } \\
\text { the village with agricultural machinery on leasing terms", a } \\
\text { joint-stock leasing company "Uzbekistan Agricultural } \\
\text { Leasing" was established. Leasing } 2005 \mathrm{y} .60 .9 \text { billion, 2000- } \\
2005 \text {. delivered more than } 7,500 \text { pieces of equipment to } \\
\text { agricultural enterprises. Local technical centers of } \\
\text { agricultural machinery plants have been opened. }\end{array}$ & $\begin{array}{l}\text { Joint ventures have been able } \\
\text { to produce modern } \\
\text { agricultural machinery and } \\
\text { provide it to the agricultural } \\
\text { sector, and as a result to } \\
\text { increase the technical and } \\
\text { technological potential of } \\
\text { agriculture. }\end{array}$ \\
\hline $\begin{array}{l}\text { Stage III } \\
\text { From } 2012 \text { to } \\
\text { the present }\end{array}$ & $\begin{array}{l}\text { Resolution of the President of the Republic of Uzbekistan } \\
\text { dated May 21, } 2012 \text { No PP-1758 "On the program of further } \\
\text { modernization, technical and technological re-equipment } \\
\text { of agricultural production in 2012-2016." The "Complex } \\
\text { measures to ensure the implementation of the program of } \\
\text { further modernization, technical and technological re- } \\
\text { equipment of agricultural production in } 2012-2016 \text { " were } \\
\text { approved. Resolution of the President of the Republic of } \\
\text { Uzbekistan dated May 15, } 2014 \text { No PP-2176 "On measures to } \\
\text { further improve the management and financial recovery of } \\
\text { agricultural machinery enterprises". } \\
\text { The holding company "Agro-industrial machinery - } \\
\text { holding" of Uzbekistan was established in the form of a } \\
\text { joint-stock company. }\end{array}$ & $\begin{array}{l}\text { The management system of } \\
\text { the agricultural machinery } \\
\text { system has been improved. } \\
\text { On the basis of the adopted } \\
\text { complex programs, the } \\
\text { technical and technological } \\
\text { potential of agriculture has } \\
\text { been raised to a new level. }\end{array}$ \\
\hline
\end{tabular}

- An important basis for increasing the technical and technological potential of the agricultural sector is the development of agricultural machinery, the holding company "Agricultural Machinery - Holding of Uzbekistan" was established by a decision in 1996, but in 2007 the structure was abolished, which left a number of unresolved issues;

- A mechanism for obtaining long-term, ie at least 20-30 years of soft loans for the introduction of new equipment or advanced technologies for agricultural enterprises has not yet been developed;
- Lack of credit resources in commercial banks for high-performance equipment or technology, lack of investment in the agricultural sector compared to other sectors of the economy;

- The initial financial difficulties of enterprises selling and leasing equipment, the relatively low solvency of agricultural enterprises, the lack of qualified personnel hinders the rapid development of the industry, etc.

In order to increase the technical capacity of the agricultural sector, we consider it 
The American Journal of Agriculture and Boimedical Engineering

IMPACT FACTOR

(ISSN - 2689-1018)

2021: $5 \cdot 554$

Published: April 21, 2021| Pages: 6-11

Doi: https://doi.org/10.37547/tajabe/Volume03Issue04-02

OCLC - 1121105746

appropriate to take the following measures in the future, including:

- It is necessary to develop and implement a mechanism to provide agriculture with domestic machinery and new technological equipment;

- Increase the amount of investment funds for the modernization, technical and technological renewal and re-equipment of agricultural machinery plants;

- Ensuring an integral link between the plant for the production of agricultural machinery and the farm, while fully taking into account the needs of farmers in machinery;

- Development of a mechanism to increase the interest of farmers in the introduction of new equipment and advanced technologies and taxation. wider introduction of financial-credit and insurance benefits, etc.

\section{CONCLUSION}

Taking into account the above, for the modernization, technical and technological renewal of agriculture, it is necessary to develop and implement systematic programs for the widespread introduction of market relations in this area and the development of a competitive environment.

\section{REFERENCES}

1. Law of the Republic of Uzbekistan "On Leasing". - Tashkent: 1999., 14 April. (“Лизинг тўғрисида" ги Ўзбекистон Республикасининг қонуни. Т.: 1999., 14 апрел.)

2. Resolution of the Cabinet of Ministers of the Republic of Uzbekistan dated March 24, 1995 No 95 "On measures to develop contractual relations in the field of production and technical services in agriculture" (www.lex.uz). (Ўзбекистон Республикаси Вазирлар Махкамасининг 1995 йил 24 мартдаги 95-сонли “Қишлоқ, хўжалигида ишлаб чиқариш-техник хизмат кўрсатиш сохасида шартномавий муносабатларни ривожлантириш чоратадбирлари тўғрисида" ги қарори (www.lex.uz).)

3. Resolution of the President of the Republic of Uzbekistan dated May 15, 2014 No PD2176 "On measures to further improve the management and financial rehabilitation of agricultural machinery enterprises". (Ўзбекистон Республикаси Президентининг 2014 йил 15 майдаги Пқ2176-сонли "Қишлоқ хўжалигининг машинасозлик корхоналарини бошқаришни янада такомиллаштириш ва молиявий соғломлаштириш чоратадбирлари тўғрисида"ги қарори.)

4. Sereda N.A. (2014) Building an effective system for monitoring and reproducing technical potential in agriculture in the region. Report of a research project supported by the Russian Humanitarian Science Foundation. - Russia. (Середа H.A. Построение эффективной системы мониторинга и воспроизводства технического потенциала в сельском хозяйстве региона. Отчет научноисследовательского проекта поддержанного российским гуманитарным научным фондом. Россия2014г)

5. Vetoshkin G.K. (1998) Cooperative forms of service and use of agricultural machinery. Achievement of science and technology in agro-industrial complex. No. 1, - pp. 36-39. (Ветошкин Г.К. Кооперативные формы обслуживания и использования сельскохозяйственной техники. Достижение науки и техники АПК.1998 г. № 1, 36-39 стр.) 
6. Gafforov A. (1988) Agro-industrial complex and chemicalization of agriculture. $\mathrm{T}$. Uzbekistan. - p. 38. (Гаффоров А. Агросаноат комплекси ва қишлоқ хўжалигини химиялаштириш. Т. Ўзбекистон. 1988 й., 38-бет.)

7. Choriev K.A. (1992) Doctoral dissertation on "Formation and improvement of the mechanism of effective use of resource potential of rural economy (in the first Republic of Uzbekistan)". - Toshkent. (Чориев К.А. “Формирование и совершенствование механизма эффективного использования ресурсного потенциала сельского хозяйства (на примере Республики Узбекистан)" мавзусидаги докторлик диссертацияси. Тошкент-1992 й.)

8. Shakhmaev M.V. (1983) The economic efficiency of the use of agricultural machinery. - Moscow. - p. 207. (Шахмаев М.В. Экономическая эффективность применения сельскохозяйственной техники. М. 1983 г., 207 стр.)

9. Husanov R.H., Hamdamov A. N, Rafiqov I.E. (2001) Service in agriculture. Problems of development of alternative machinetractor fleets. - Tashkent. (Хусанов P.Х., Хамдамов А. Н, Рафиқов И.Э. Қишлоқ хўжалигида сервис хизмати. Муқобил машина-трактор паркларини ривожлантириш муаммолари. Тошкент 2001.)

\section{Websites:}

1. http://textbook.ru/catalogue/book:

2. http://web.book.ru/cgibin/book.plpageқ4\&bookқ88899 